\title{
Empowerment of Women Farmers Group through Processing of Agricultural Products in Hargomulyo Village, Kokap, Kulon Progo Yogyakarta
}

\author{
Suratna, Adi Soeprapto, Susanta, Simon Pulung Nugroho \\ Universitas Pembangunan Nasional Veteran Yogyakarta \\ E-mail address suratno66@yahoo.co.id; E-mail address adi_soeprapto@upnyk.ac.id* \\ E-mail address su_santa@yahoo.co.id; E-mail address simonpulung@gmail.com
}

\begin{abstract}
Kulon Progo is a district known as one of the centers for agricultural products in the Yogyakarta Special Region Province. Agricultural product processing efforts in Kulonprogo Regency still face challenges in terms of optimal community capacity and capabilities, especially as found in Hargomulyo Village, Kokap District. These Community Engagement Activities are intended for employment and increasing citizen participation, especially women in development through community empowerment. The Mekar Mandiri Women Farmera Group is a group of women farmer's wives or women in Hargomulyo Village who have activities in the agricultural sector in utilizing agricultural resources to work together to increase farm productivity and the welfare of its members. In carrying out its activities, the Mekar Mandiri Farmer Group has several obstacles: (1) Limited insight into developing agricultural business; (2) Limited skills in processing agricultural products; (3) Limited equipment for processing agricultural products. The solutions offered in Community Engagement activities are (1) training to broaden people's insights and capacity building, (2) facilitation of business equipment procurement, and (3) assistance in applying for home industry permits and trademarks. The conclusion that can be drawn from this community engagement activities are the development of an entrepreneurial spirit and increase the skill and ability of women farming groups member to process garden products (post-harvest).
\end{abstract}

Keywords: community empowerment, women farmers group

\section{INTRODUCTION}

This is an open access article under the CC-BY-NC license.

Hargomulyo Village is one of the villages in the Kokap Kulon Progo District of Yogyakarta which has high agricultural potential. Fertile land with hilly natural conditions, vast land, this village community relies on the plantation sector for their livelihoods. Generally, the residents plant coconut and cacao trees because they are very suitable for local natural conditions, besides that there are many banana plants and so on. 
Efforts to manage agricultural and plantation products in Hargomulyo Village have been carried out by women. These women form a group of women farmers, namely the Mekar Mandiri Women Farmer Groups. The main activity is the processing of coconut garden products, such as processing sap into brown sugar and ant sugar. It also carries out the processing of crops grown in gardens such as bananas, gadung, mbili, arrowroot, kimpul / taro, uwi, kolang kaling into snacks

The problems that occur in efforts to process agricultural and plantation products in Hargomulyo Village are as follows: 1). the number of crops such as. and banana, gadung, mbili, arrowroot, kimpul / taro, uwi, kolang kaling have not been processed optimally into more valuable products. Farmers immediately sell their plantation products to the market without processing them, indeed this can be a source of income although the income earned is relatively low; 2) the generation that cultivates coconuts and processes coconut juice, only the parents and young generation do not want to manage it because they think that the income from coconut plantation and processing coconuts cannot meet their daily needs, so most of the young men migrate to the city. 3). The female farmers only process the sap into sugar, they cannot process other plantation products into more valuable products

Picture 1. Administrative map Hargomulyo Village

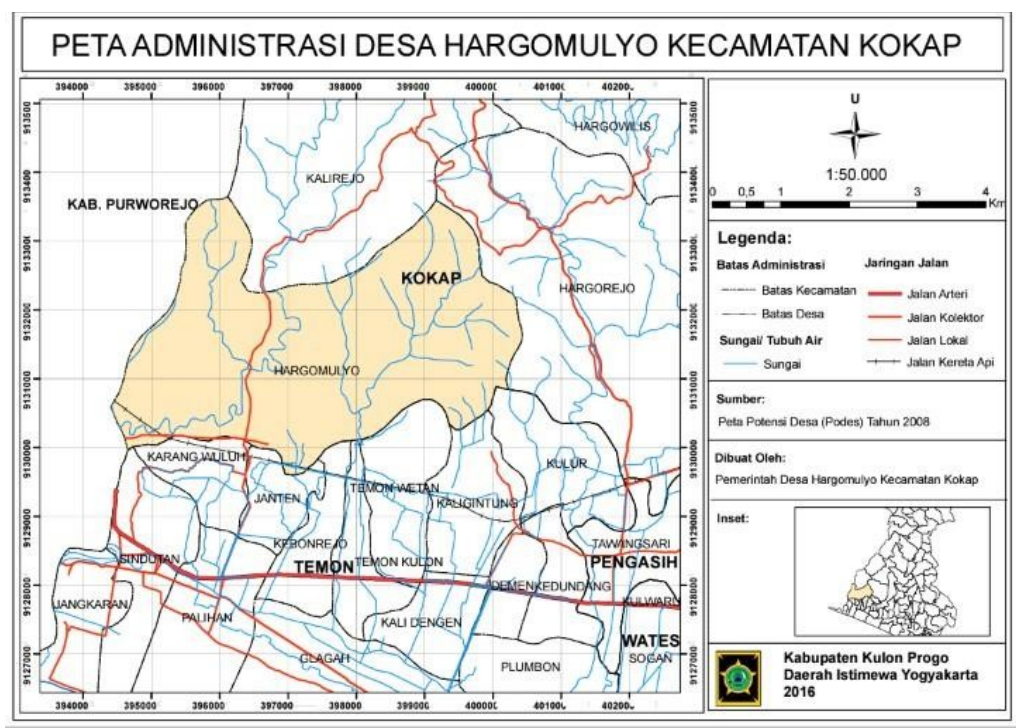

Source: Kulon Progo District, 2017

Based on the problem statement and The Declaration of the Summit on Food Availability (FAO 2009) that identified women farmers as a key target in efforts to address food security issues. Furthermore, Rahmadanih et al. (2015) in their study emphasized the strategic role of women farmers that not just involved in the process, purchase, and prepare food, but also produce good crops for consumption or sale. The objective of this study are (1) developing of an entrepreneurial spirit among members of the Mekar Mandiri Women Farmers Group; 2) Improving the ability of women farmers group member to process plantation products (post-harvest). 


\section{LITERATURE REVIEW}

Agriculture has an important role in human life because it functions as a provider of food, feed for livestock, and bioenergy. In Indonesia, the agricultural sector has a very strategic role in supporting the national economy, especially in realizing food security, increasing competitiveness, absorbing labor, and reducing poverty. Also, encouraging the growth of downstream agro-industry and spurring exports of agricultural commodities to increase foreign exchange.

\section{II.1. Community Empowerment}

Empowerment comes from the word "power" which means strength or ability, then empowerment is interpreted as a process of obtaining power, strength or ability, dana tau giving power, strength or ability from parties who have power to parties which lacks or does not have power, ability or strength (Yuliana, 2017). The concept of community empowerment is a critical response to a centralized and uniform development pattern in Indonesia. As a concept, community empowerment is rooted in a human-oriented development paradigm (Kolopaking, Septianto, Ambarita, 2019).

In the context of rural communities by referring to Law 6 of 2014 concerning Villages, it explains community empowerment as stated in article 1 paragraph 12 states that empowerment of rural communities to develop community independence and welfare by increasing knowledge, attitudes, skills, behavior, abilities, awareness, and utilize resources through the establishment of policies, programs, activities, and assistance by the essence of the problem and the priority needs of the rural community. The target and objectives of empowerment as summarized by Mustanir et al. (2019) are aimed at a person's ability, especially the poor and vulnerable groups so that they have the ability to (1) fulfill their basic needs so that they can be free from these basic needs, (2) show productive sources that enable them to increase their income and obtain the goods and services they need, (3) participate in the development process and the decisions that affect them.

The empowerment program must place the community as the subject, by creating a program that mainstreams the needs of the community and will generate participation and a sense of belonging in the community. In implementing the empowerment program, it is necessary to encourage social entrepreneurship to be oriented towards the interests of the wider community, in this case, the welfare of the rural community. Social entrepreneurship as stated by Pratama (2019) is an ethos, enthusiasm, and/or approach that aims to solve social issues with the principle of promoting innovation, collaboration, network development, the ability of creativity to see new opportunities, and the practice of providing added value by exploiting resources. available (economic, social, cultural, and political) through the adoption of entrepreneurial principles. With this spirit of social entrepreneurship, it is expected that the rural community can explore opportunities as well as solutions to social problems independently.

Furthermore, the success of the empowerment program is also determined by the synergy between sectors. Synergy can be defined as a combination or combination of elements or parts that can produce better or greater output (Kurniawan and Suryawati, 2017). Multistakeholder synergy will provide an opportunity for each party to contribute effectively by their competence and assignments. 


\section{II.2. Women Farmer Groups}

According to Kurniyati et al. (2014), women farmer groups are groups of wives of farmers who help and or have an agricultural, fishery, and forestry business activities that grow based on familiarity, harmony, and shared interests in utilizing agricultural resources to work together to increase farm productivity to increase family income and welfare. Women Farmers Group (KWT) is a forum that provides opportunities for women to take part in advancing the agricultural sector. In this case, Yuliana (2017) explains that the Women Farmer Group can carry out the following roles: 1) learning class, as a forum for each member to interact to increase knowledge, skills, and attitudes in better and more profitable farming, and more behavior. independent to achieve a more prosperous life; 2) farming production unit, as a unit of farming to realize cooperation in achieving a more profitable economic scale of the business; 3) a vehicle for cooperation, as a place to strengthen cooperation among members of the women farmer groups and between women farmer groups and other women farmer groups as well as with other parties to face various threats, challenges and obstacles, and disturbances.

However, the existence of Women Farmer Groups is still underdeveloped, this is due to the lack of empowerment of women, as indicated by Yuliana (2017) as follows: 1). The low involvement of women in development programs so that women play a more role as objects of development programs. 2). There is still a lack of women's ability in terms of leadership, to improve their bargaining position and to be involved in every development, either as planners, implementers or in monitoring and evaluating activities. 3). The low level of competence of women in home industry production. 4). The low level of involvement of women in organizations at the local level where they live.

Base on these, Yuliana (2017) emphasizes that empowerment of women farmer groups will give women the ability to gain access and control over resources, economy, politics, social, culture so that women can organize themselves and increase self-confidence to be able to play a role and participate actively in solving problems, to build abilities and self-concept. In other words, empowerment will provide women farmers group to be more independent, which comprises some aspects (Mustaffa and Asyiek, 2015): 1) material independence (productive ability in meeting material needs), 2) intellectual independence (ability and strength control), 3) attitudinal independence (self-awareness, initiative, motivation, selfbelief, decision-making for actions, and 4) managerial independence (the ability to build, implement and organize collective activities), all to make changes in the farmers' lives.

\section{RESEARCH METHODOLOGY}

The method used in the implementation of this community engagement activity is to increase the knowledge and skills of the Women Farmers Group through training, piloting, and mentoring by using the PRA (Participatory Rural Appraisal) method. According to Hudayana et al. (2019), PRA is an action research method developed to increase community participation in development developed by Robert Chambers, which allows village communities to play an active role in expressing and analyzing their situation and optimally planning and implementing this commitment in their village. 
The PRA method was developed with the following reasons: (1) organizing activities with the community to strive to fulfill practical needs and improve community welfare as well as a means of the learning process, (2) it can bring a vision to achieve community empowerment and social change through community development using a learning approach, (3) farmers can directly discuss and see examples of activity results. This level of community participation is achieved when community organizing leads to the stage of self-liberation to the level of self-mobilization.

The approach used is training and mentoring. This approach is felt to be the most appropriate to solve the problems faced by partners. Through mentoring, strategic, and technical aspects can be carried out. Assistance is also expected to be able to ensure that improvement programs are carried out consistently. The training will provide additional insight and understanding for partners. The target group that is the target of program intervention is the Mekar Mandiri Women Farmers Group, Hargomulyo Village Kokap Kulon Progo District.

\section{FINDING AND DISCUSSION}

Based on the community service program activities that have been carried out so far, the following are the results that have been achieved:

\section{IV.1. Socialization of Activities}

This activity was carried out by the Community Service Team assisted by field assistants to convey information about the implementation of community service to members of the Mekar Mandiri Women's Farmers Group, hamlet heads, and community leaders of Hargomulyo Village. This is intended so that the Women Farmers Group and the community get an understanding of the scope and stages of implementing community engagement activities. The socialization was held at the Mekar Mandiri Women Farmers Group Secretariat. With this socialization, it is hoped that both partners, government officials, and the community will get adequate information about the implementation of community service in Hargomulyo village.

\section{IV.2. Entrepreneurship Training}

The implementation of this entrepreneurship training is intended to foster an entrepreneurial spirit among the members of the Mekar Mandiri Women Farmers Group. This is a followup to the results of observations by the community service team which found problems in the Mekar Mandiri Women's Farmer Group, where women farmers do not have the desire to develop as apart from processing sugar even though many other commodities can be developed. The entrepreneurship training material emphasizes the aspect of providing motivation to members of the Women Farmers Group to continue to develop themselves, not being satisfied with existing conditions and being able to see opportunities and develop them into activities that have added value in the economic field by utilizing local processed materials available in the Hargomulyo Village area.

\section{IV.3. Procurement Of Equipment For Processing Agricultural Product Into Snacks}


The procurement of this equipment is intended to increase the capacity of women farmer groups who are partners in community service programs. The procurement of this equipment is by the request of the woman farmer group, which the community service team received when conducting the initial survey and during entrepreneurship training. In this case, the equipment needed by the women farming group is production equipment for the manufacture of chips made from the crops of tubers and coconut as an effort to increase added value from plantation crops through diversification of processed products based on local food ingredients.

The processing equipment consists of 1) a multipurpose chopper/cutter used to cut cassava/tubers into thin and small pieces according to the processed chips product; 2) a spinner machine that functions to drain the oil after frying the chips so that they can produce crispy chip products; 3 ) sealer, is a tool used to glue plastic packaging which ensures that the packaging of the chip product is tightly closed so that the chips are not easily sluggish and are durable.

Figure 2: Delivery of Snack Food Processing Equipment

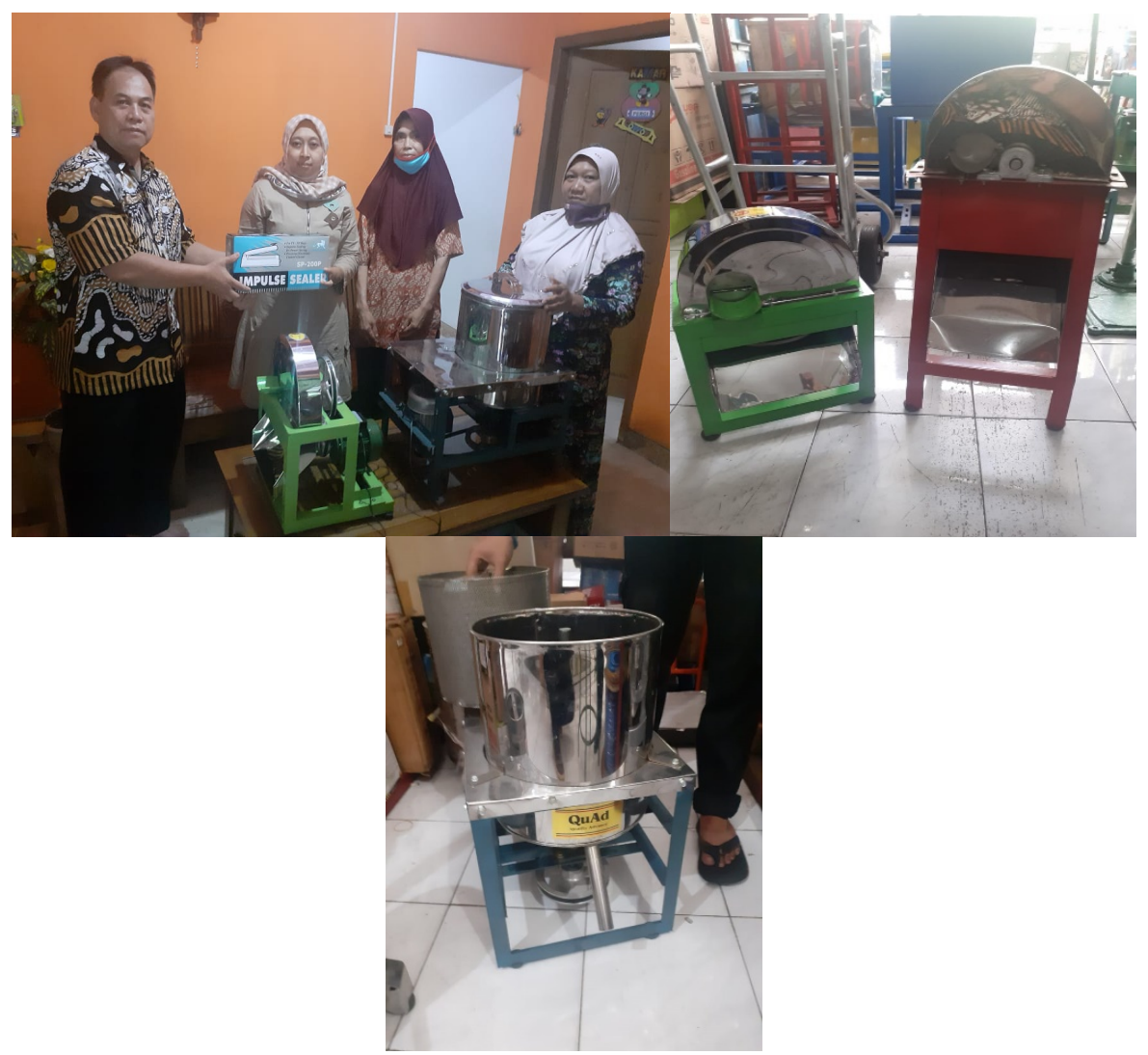

Source: UPN Veteran Yogyakarta Community Engagement Team, 2020

According to the Head of the Mekar Mandiri Women Farmers Group, she felt very helped 
and appreciated the assistance in procuring this equipment by the community service team. The availability of this equipment will provide additional productive activities for women members of farmer groups in processing plantation products into snack products that have higher economic added value, as well as diversifying agricultural products.

\section{IV.4. Agricultural Product Processing Training}

This agricultural product processing training is conducted using a practical training approach. The training material is about the process of producing cassava chips by utilizing local raw materials which are agricultural products in Hargomulyo Village. The practical approach is carried out by emphasizing the demonstration of skills and the ability to process plantation crops into processed snack chips.

\section{Figure 3: Snack Production Practical Training}

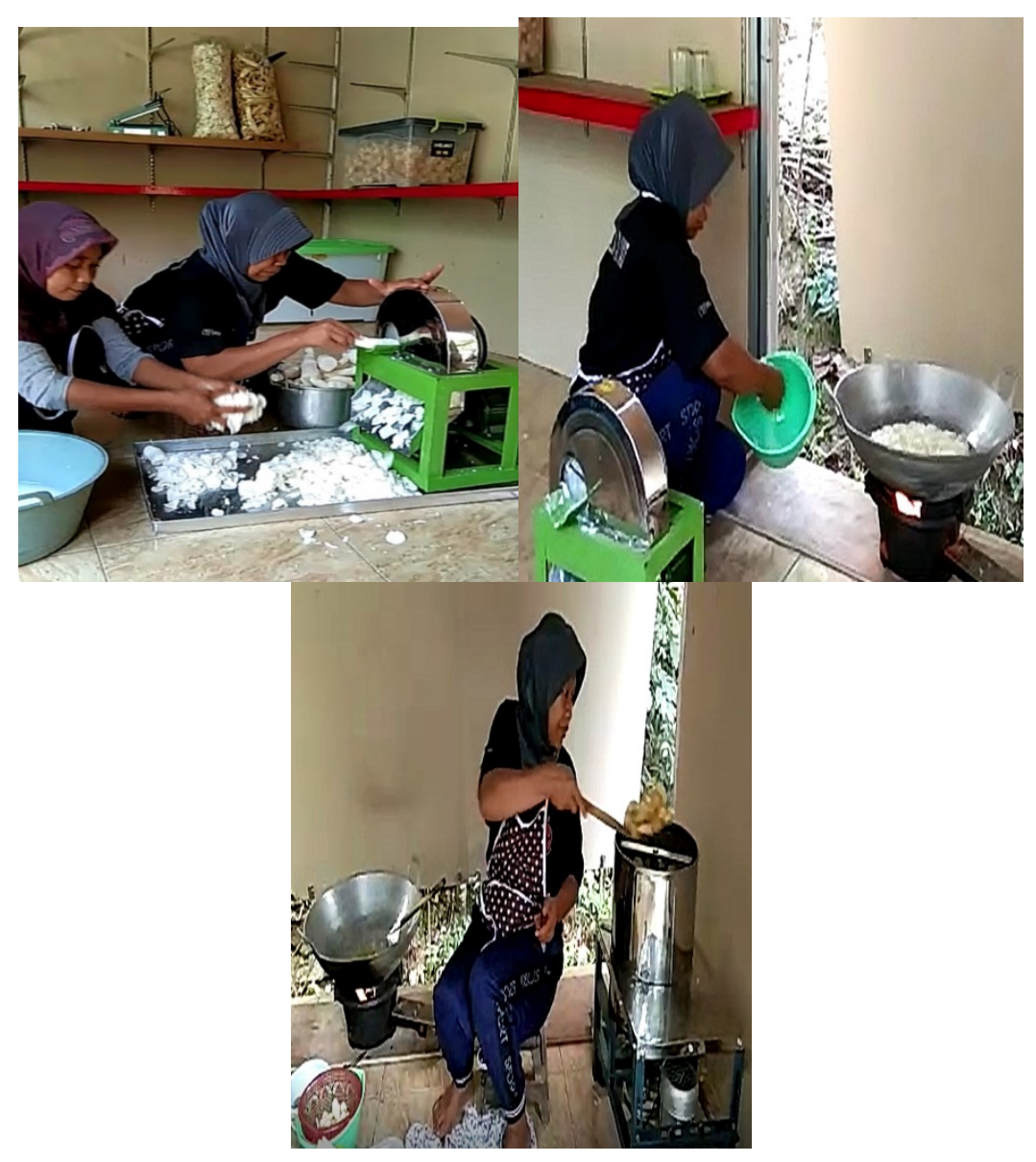

Source: UPN Veteran Yogyakarta Community Engagement Team, 2020

The participants felt very enthusiastic and earnest during the training, as expressed by one of the participants who stated that this practical training allowed her to be directly involved in practicing snack making with the community engagement team's assistive equipment. 


\section{IV.5. Assistance in the Issuance of Processed Food Products Distribution Permits}

Household scale food products distributing in the community must obtain legality related to the security and feasibility of consumption assurance from the Government. This distribution permit is in the form of PIRT (Pangan Industri Rumah Tangga), which is an official guarantee from the government to be circulated and safe for consumption for all consumers. PIRT is issued through a supervisory body, namely the Health Service in a certain district.

The existence of legality fit for distribution in the form of a PIRT license for a snack product business produced by the Mekar Mandiri Women's Farmer Group will guarantee that the raw material processing to processing and production is by the terms and conditions of food safety so that it is safe for public consumption.

Assistance activities for the issuance of a PIRT certificate for snack products from the Mekar Mandiri Women Farmer Group are carried out because the legalization made by the government through the Kulon Progo District Health Office is carried out on submissions made by producers of their own will, so active efforts from the producer are needed to carry out the submission process PIRT. In this case, the community engagement team assisted in the process of completing the required documents for submitting a PIRT and assisting in registering the PIRT permit application to the Kulonprogo District Health Office.

IV.6. Assistance In Labeling And Packaging For Agricultural-Based Snack Products. Product packaging and labeling have an important role in terms of product protection as well as product promotion media to attract consumer attention by providing information about the product itself. Attractive packaging designs and informative labels are the keys for producers to be able to communicate their products to their consumers. The purpose of this mentoring activity in making labels and the product packaging is to assist the Mekar Mandiri Women's Farmer Group in designing packaging designs and inclusion of appropriate labels on snack food products. The results of designing snack product packaging labels can be presented as follows :

Figure 4: Snack Product Label Design
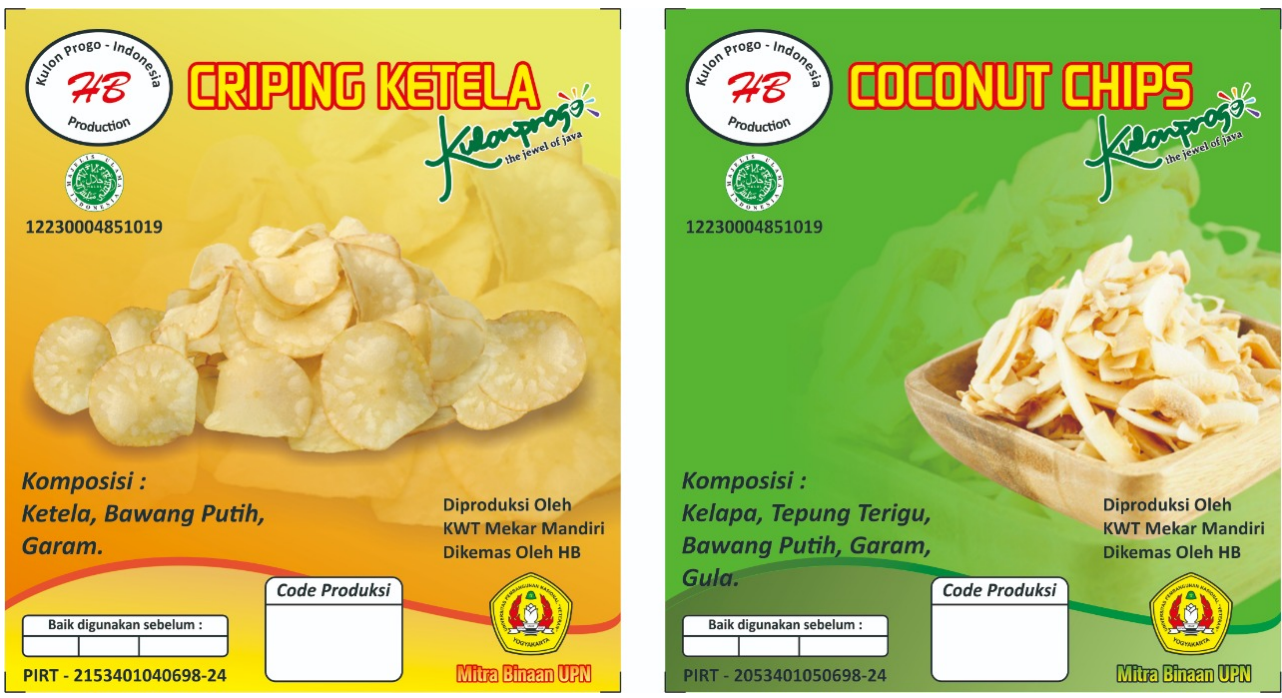
Source: UPN Veteran Yogyakarta Community Engagement Team, 2020

In the product label design, there is at least some information that can be conveyed, including product name, name of the producer, address of producer, product composition, production code, expiration date, product legality statement.

\section{IV.7. Small Business Management Training}

This kind of business management training is intended to increase the knowledge and ability of the Mekar Mandiri Women Farmers Group in terms of business management which includes aspects of business governance and undertaking business development efforts so that the training participants are expected to be able to run and sustainably develop a business. The training material is related to the business organization including aspects of leadership, human resources, marketing, and finance as well as business development through the preparation of a business plan.

\section{CONCLUSION AND FURTHER RESEARCH}

\section{V.1. Conclusion}

Based on the results of the achievements of empowerment activities in the Mekar Mandiri Women's Farmer Group, it can be concluded that:

1. The Women Farmers group has an entrepreneurial spirit and motivation to develop products from crops into processed products that have higher economic added value in the form of snack products.

2. The implementation of empowerment activities has been able to increase the knowledge and skills of members of the Women's Farmers Group in diversifying local agricultural products based on processed products and making it a productive household-scale business that has the prospect of being an independent source of income for female farmer households.

\section{V.2. Suggestion}

As for the things of concern in the future, there are as follows:

1. Village community empowerment efforts must be carried out sustainably. This is so that the existing process can be monitored continuously as well as to seek development opportunities in the future.

2. In connection with the development of information technology that has an impact on the emergence of industry 4.0, efforts to empower rural communities must also consider aspects of mastery of information technology. In this case, the development of household business governance in the future must also involve information technology to increase business productivity and expand market share.

\section{REFERENCES}

Hudayana, Bambang, Pande Made Kutanegara, Setiadi, Agus Indiyanto, Zamzam Fauzanafi, Mubarika Dyah F.N., Wiwik Sushartami, dan Mohamad Yusuf, (2019), Participatory Rural Appraisal (PRA) untuk Pengembangan Desa Wisata di Pedukuhan Pucung, Desa Wukirsari, Bantul, Bakti Budaya, 2(2):99-112 
Kolopaking, Lala M, Septianto, Marzuqo, Ambarita, Ervan, (2019), The Synergy of Village Developing Management through Corporate Social Responsibility Activities, Sodality: Jurnal Sosiologi Pedesaan, 7(2): 102-109.

Kurniawan, Jovi Andre and Suryawati, Retno, (2017), Sinergitas antar Stakeholders dalam Pengelolaan Ruang Terbuka Hijau (RTH) Taman Kota di Kota Temanggung, Jurnal Wacana Publik, 1(1):39-45.

Kurniyati, Yuli, Fitri Rahmawati, Pulut Suryati, (2014), Optimalisasi Pemanfaatan dan Diversifikasi Olahan Pangan Lokal Sebagai Upaya Pemberdayaan Masyarakat, Inotek, 18(1):1-15

Mustaffa, Che Su, Asyiek, Fauziah, (2015), Conceptualizing Framework for Women Empowerment in Indonesia: Integrating the Role of Media, Interpersonal Communication, Cosmopolite, Extension Agent, and Culture as Predictors Variables, Asian Social Science, 11(16): 1-15.

Mustanir, A, Hariyanti Hamid, Rifni Nikmat S, (2019), Pemberdayaan Kelompok Masyarakat Desa dalam Perencanaan Metode Partisipatif, Jurnal Moderat, 5(3):227-239

Pratama, Denny Riezki (2019), Peran Kewirausahaan Sosial dalam Pemberdayaan Masyarakat: Tiga Cerita dari Kutai Timur, Umbara: Indonesian Journal of Anthropology, 4(2):115-129

Rahmadanih, Sitti Bulkis, Andi Amrullah, Rusli M.Rukka, M.Arsyad, (2015), Strengthening Institutional Model of Women-Farmers Group in Developing Household Food Diversification, International Journal of Agriculture System (IJAS), 3(1): 29-40.

Yuliana, Dina, (2017), Pemberdayaan Perempuan oleh Balai Penyuluhan Pertanian (BPP) melalui Kelompok Wanita Tani "Mekar Asri" di Dusun Mekar Mukti Desa Pasirmukti Kecamatan Cineam Kabupaten Tasikmalaya, Dinamika : Jurnal Ilmu Administrasi Negara, 4(3):417-423. 